\title{
NATIONAL EDUCATION POLICY: EDUCATION DEVELOPMENT MASTER PLAN - CHARTING THE FUTURE
}

Haili Dolhan \& Naimah Ishak

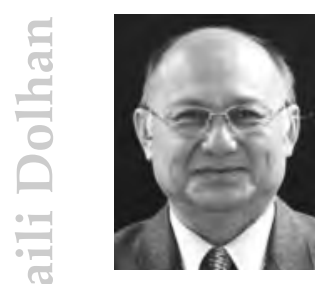

Is currently the Deputy Director General (Policy and Education Development) Ministry of Education Malaysia. Holds a B.A. (Hons) in Geography (University of Malaya, K.L.), an M.A. in Guidance and Counseling (University of Durham, U.K.) and Doctor of Philosophy (Education) in Human Resource Planning (Birmingham University, U.K.). He is also a qualified teacher (Certificate of Teaching from Temenggong Ibrahim Teacher's College, Johor Bahru).

He has been in the education service for the last 35 years. Is responsible in the team of the planning of the Education Blue Prints (20062010), rural education development especially remote and island schools in the state of Sabah and Sarawak, in studying of curriculum reform, primary and secondary education assessment reform and looking at the present and future education policy and development. E mail: [haili@lpm.moe.gov.my].

Principal Assistant Director, Educational Planning and Research Division, Policy Planning Unit, Ministry of Education.

E mail: [naimahishak@yahoo.com].

\section{ABSTRACT}

Upon gaining independence from the British colonial occupation in 1957, Malaysia believes that education is instrumental to the development of the nation's economy. Thus, educational development in Malaysia is based upon increasing access to education, increasing equity in education, increasing quality in education and improving efficiency and effectiveness of education management. 
Secondly, the development of education in Malaysia reflects the multifaceted role it assumes in creating a progressive and united Malaysian society towards enhancing the quality of the lives of our children and generations to come.

Hence, no one should be excluded from the mainstream of development. At the same time, the mindsets, cultures and values which the people and social institutions are imbued with need to be strengthened in line with the nation's aspirations to progress in its own mould.

In implementing these goals, the MOE (Ministry of Education) has formulated the Education Development Master Plan (EDMP) 2006-2010 as a comprehensive and integrated master plan for education development under $9^{\text {th }}$ Malaysia Plan (9MP). EDMP was developed in line with the national development plans and policies by taking into account the Third Outline Perspective Plan, Five Year Malaysia Plans, the framework laid out in the National Mission, the National Integrity Plan and others including national education development plans and policies. The plan is aimed at «Pioneering Change: A National Mission» and put forward the policies the policies, goals, strategies, priorities, actions plans, key performance indicators, time-lines and budget for education development.

Key Words: education; Malaysia; development; policy; plan.

\section{RESUMEN}

Una vez ganada su independencia de la ocupación colonial británica, en 1957, Malasia cree que la educación es un instrumento para el desarrollo económico de la nación. Así, el desarrollo educacional en Malasia se basa en un acceso creciente a la educación, ampliando su grado de equidad, incrementando su calidad, y mejorando la eficiencia y efectividad en el manejo o gerencia de la misma.

Secundariamente, el desarrollo de la educación en Malasia refleja el rol multifacético y crea una sociedad unida y en progreso, enfocada en una meta: hacer posible la calidad en las vidas de los niños y de las generaciones por venir. 
Nadie debería ser excluido de esta corriente de desarrollo. Al mismo tiempo, los modos de pensar, las culturas y los valores en los cuales el pueblo y las instituciones sociales están imbuidos, deben fortalecerse mediante las aspiraciones de progreso de la propia nación.

En la implementación de estas metas, la MOE (Ministry of Education) ha formulado el Plan Maestro de Desarrollo de la Educación 2006-2010 («Education Development Master Plan, EDMP»), trazado como un amplio e integrado plan maestro para el desarrollo de la educación bajo el $9^{\circ}$ Plan de Malasia (9MP).

El EDMP fue desarrollado en línea con los planes nacionales de desarrollo y con las políticas, tomando en cuenta el Tercer Plan de Perspectivas Generales, Planes de Cinco Años para Malasia, la estructura provista en la Misión Nacional, el Plan de Integridad Nacional y otros, incluyendo los planes de desarrollo educativo y sus políticas. El plan está dirigido a ser un «Cambio Pionero: Una Misión Nacional», acompañando a las políticas, metas, estrategias, prioridades, planes de acción, indicadores clave de rendimiento, líneas de tiempo y presupuestos para el desarrollo de la educación.

Palabras clave: educación; Malasia; desarrollo; política; plan.

\section{INTRODUCTION}

1.1. Malaysia believes that education is instrumental to the development of the nation's economy. The nation building process in Malaysia involves the creation of a progressive and united Malaysian nation based on a resilient economy that is characterised by an equitable and just distribution of wealth. Besides achieving a dynamic economic growth, imbalances in economic opportunities and income source must not adversely affect national development. With the advent of Vision 2020, no one should be excluded from the mainstream of development. At the same time, the mindsets, cultures and values which the people and social institutions are imbued with need to be strengthened in line with the nation's aspirations to progress in its own mould. 
2.14. The overall thrusts for educational development in Malaysia is based upon increasing access to education, increasing equity in education, increasing quality in education and improving efficiency and effectiveness of education management. The purpose of this paper is to share the implementation of educational development in Malaysia and its implications to national development. It discussed the phases of educational development in Malaysia to enable the readers to gain insight into the multifaceted role of education vis-à-vis the many factors that influence change and Malaysia's recent initiatives in education. The discussion will stem from Malaysia's National Vision and the role of education in attaining this vision. This paper will also focus on the interrelation of the strategies with the overall education development thrusts so that every dimension of an individual's development potential is taken into consideration.

\section{UNDERSTANDING EDUCATIONAL DEVELOPMENT IN MALAYSIA}

2.1. Malaysian education has undergone an evolution consistent with national development and capacity. This evolution encompassed five phases, which are the Pre-Independence (Prior to 1957); Post-independence (1957-1970); New Economic Policy (1971-1990); National Development Policy (1991-2000); and National Vision Policy (2001-2010).

\section{Pre-independence: The British colonial education policy (prior to 1957)}

2.2. Before independence, education under the British colonial was under the «divide and rule» policy. The formal period of British colonization in Malaysia (1874-1957) witnessed the development of British education policy that catered to the various ethnic groups in four separate school systems aiming at colonial administration's different objectives. The Malays were provided with minimal reading, writing, and mathematic skills also were trained in vocational skills in order to become better farmers and fishermen. The Chinese and Tamil curriculum was patterned after their immigrant mother countries; textbooks and teachers were imported from their mother countries to reinforce 
cultural tradition. Conversely, English schools looked to England for their inspiration and modelled their curriculum after the one in Great Britain.

2.3. There were no avenues provided for the people to attend a «common school» to enable the children of different races to communicate and understand each other's cultures and values. Only in the English schools did the children have the opportunity to study together. The seeds of separatism among the three major ethnic groups were sown by the British colonial government. In line with the «divide and rule» policy, the British colonial government discouraged the setting up of the "common school». The policy imposed by the British colonial government had allowed them to administer the country without much reaction and opposition from the society.

\section{Post-independence: Reengineering of the Malaysian Education Policy $\underline{(1957-1970)}$}

2.4. One of the challenges faced by the Malaysian government after the decolonisation of the land from the colonial rule in 1957 was to promote national unity through a national education system. There was an awareness established to study the school system. Several committees were established to study the school system and the recommendations were embedded in the following reports and policy documents:

- Barnes Report (1951) - reviewed and improved Malay education;

- Fenn-Wu report (1951) - reviewed Chinese education;

- Education Ordinance (1952) - recommended national schools as the model for the national school system; and

- Razak Report (1956) - laid the foundation for the development of the education system to foster unity through the National Education System with Malay language as the main medium of instruction, a national curriculum, syllabus and a common examination system for all schools.

2.5. The recommendations of the Razak Report were reviewed by the Rahman Talib Committee in 1960 and its recommendations became the 
basis to formulate the Education Act 1961 which outlined the Malay language as the main medium of instruction at all levels of education including the use of a common curriculum and examination for all students.

2.6. The Education Act 1961 provided free universal primary education. For the first time, access to primary education was afforded to all children in the country. Enrolment over the years increased rapidly ranging from 1.2 million in 1965 to 1.6 million in 1970. The government initiative was to create a literate society that would elevate them and help to evolve to a higher level of thinking.

\section{New Economic Policy: Access and Equity in education - Narrowing the Gaps}

$\underline{(1971-1990)}$

2.7. Socio and economic issues shaped the development of education from the seventies to 1990. Racial harmony and eradication economic imbalances in the society were crucial to sustained development, stability and progress. This was the period of the New Economic Policy, which is a socio-economic policy to achieve national unity and development by focussing on eradication poverty and restructuring the Malaysian society to eliminate the identification of race with economic function and geographical location. Raising the income of the poor, closing the disparity between the urban and rural people, increasing production and creating more opportunities.

2.8. The 1969 unrest was seen as the wake up call to the ministry of Education (MOE) calling for attention to the need to re-emphasise national unity in a multi-ethnic society. The education system responded by reorientation and transforming its initiatives to cater for the social and economic imperatives of the nation. A more equitable system of education became the catalyst for economic development. This was a period of rapid qualitative expansion, particularly, in terms of educational facilities, infrastructure, access and opportunities. It has brought into the perspective the fact that racial harmony and economic imbalances in the society is crucial to sustained development, stability and progress. Education was aimed at strengthening national unity through poverty eradication among all races and the restructuring of society. During this 
period, education was the means to redressing social imbalances by providing equal education opportunities to all.

2.9. The provision of education, which thus far concentrated around urban centers moved into rural areas. More schools were built in the rural areas and greater access was given to rural children and the economically disadvantaged. It was during these decades that saw the emergence of fully residential schools, special science school, rural school hostels, the Textbook Loan Scheme and educational television, expansion and extension in the provision of scholarships, school meal and health programmed.

\section{National Development policy: Managing and Coping with Change}

$$
\underline{(1991-2000)}
$$

2.10. Since we are dealing with the realities of the $21^{\text {st }}$ century, the educational reform has to be present and has a view for the future. The role of education has become contemporary, forward thinking, societal relevant, and a prerequisite to realizing Malaysia's Vision 2020. This is to enable the education system to develop a world-class quality education system to promote national unity, produce human resources for national development, and developed a progressive and disciplined society. Some of the areas of reforms are formulating legislations on education, developing a scientific and technological society, enriching and diversifying the curriculum, promoting higher education reforms, upgrading teacher education, and promoting organisational changed.

\section{The National Vision Policy (2001 - current)}

2.11. Globalisation, liberalisation, internationalisation and the development of information and communications technology (ICT) are among the main new challenges confronting the nation in the $21^{\text {st }}$ century. In addition, Malaysia also faces the challenge of developing a knowledge-based economy or k-economy. In this context, the MOE provided educational development programmes to produce citizens who are knowledgeable, ICT literate, skilled and possess good moral values. 
To relevance and competitiveness, all educational programmes and projects that have been planned are constantly renewed, reinforced, restructured and reformulated.

2.12. Efforts to develop the human capital must be done in a holistic manner, with emphasis on the mastery of knowledge, intellectual capital including the sciences, technology and entrepreneurship, inculcation of a progressive attitude, as well as the practice of high values, ethics and morals as emphasized in the National Integrity Plan. The National Mission advocates the development of human capital with first class mentality and people-centered capacity building as the main approach towards achieving the developed nation status by the year 2020. To achieve high performance and maximum impact from development, the National Mission has outlined five thrusts as shown below.

\section{Thrusts of the National Mission}

Thrust 1: Improving the value-added economy

Thrust 2: Enhancing knowledge and innovation capacity of the nation and nurture a first class mentality

Thrust 3: Continuously addressing socio-economic imbalances in a constructive and productive manner

Thrust 4: Enhancing and sustaining the quality of life

Thrust 5: Strengthening institutional capacity and implementation

2.13. Education plays a crucial role in ensuring the successful implementation of the five of the National Mission. The second and third thrusts of the National Mission are directly related to the role of education:

I. The second thrust - Enhancing knowledge and innovation capacity of the nation and nurture a first class mentality focuses on these following aspects:

- Implementing comprehensive improvements on the delivery system of education and training;

- Making national schools as the «school of choice» among Malaysians; 
- Bridging the gap between rural and urban schools;

- Offering greater opportunities and access to quality education, training and lifelong learning at all levels;

- Nurturing an innovative science and technology society;

- Strengthening national unity and developing a society with progressive perspectives and exemplary value systems; and

- Widening discussions among the government, private sector, parents and society on human capital development

II. Thrust 3 - Continuously addressing socio-economic imbalances in a constructive and productive manner focuses on these following aspect;

- Increasing the income for the lowest 40 percent of households by improving productivity through human capital development;

- Bridging the rural-urban between states and territories through sustainable income generation and improved access to basic needs including education;

- Bridging the digital divide between urban and rural schools; and

- Widening access to educational and training programmes to increase the number of bumiputera managers and professionals, especially in the private sector.

2.14. In ensuring the success of the National Mission, the MOE has taken the initiatives to re-look and strengthened current educational policy so that it is tandem with national development. Thus, MOE has prepared a comprehensive Education Development Master Plan (EDMP) which outlines the focus, main strategies and implementation plans to make national education relevant to current and future needs. Any gaps or deficiencies in education will be given due attention. The process of analysing the history, development and achievements in education is crucial in outlining the strategies of the EDMP.

\section{NARROWING THE GAPS IN EDUCATION}

3.1. Since independence, the main thrust of education development is to increase access to education equity in education and increase quality of education. Initiatives have focused on the hardware, software and people 
components. Despite the many success, the MOE realizes the narrowing the gap in education, between the high ends and the low ends i.e. between the high achievers and low achievers (boys, girls, ethnic groups, Orang Asli and the ethnic minorities), rural-urban divide, digital divide and special education needs, is crucial in meeting the goal of providing equitable access and quality education for all. Thus, the MOE will continue its efforts in addressing new challenges and fulfilling the needs in education, including:

- Inadequate supply of basic facilities especially 24 hours electricity supply and clean water particularly in rural schools;

- Insufficient classrooms and the high number of double-session schools;

- Insufficient science laboratory facilities;

- Low rate of student participation at the secondary level;

- Primary schools pupils who have not mastered the reading, writing and arithmetic skills (3Rs);

- Further reducing dropout rate among students, especially those under the MOE schooling system;

- Improving the participation and achievement of students with special needs and children of the Orang Asli and Penan;

- Inadequate numbers of trained teachers in critical subjects such as English, Mathematics and Science, particularly in the rural and interior areas.

3.2. MOE allocates more than RM1.0 billion every year to assist student from poor families and the disable through various support programmes such as :

a. Supplementary Food Plan (SFP) and School Milk Programme (SMP) The SFP was first implemented in 1979 to provide nutritious food to needy students. Beginning 2003, students were provided with fresh milk under the SMP. It is a compliment to the SFP programme, specifically for the poor and under-privileged pupils. Under the programme the student will receive a packet of milk per week as they are provided with additional food, while the poor students will receive two packets of milk per week; 
b. Poor Students' Trust Fund - The fund was set up following the implementation of compulsory education in 2003 to help poor students to pay fees and buy uniforms. This would prevent them from leaving the education system due to poverty;

c. Transport Assistance - The MOE provides transport assistance to students. For fully residential school, the transport assistance is in the form of return fare from home to school. Regular schools with hostel facilities use the allocation for educational visits and as transport fares to religious schools or mosque. For other schools, this assistance is used to support educational tours.

d. Tuition Voucher Scheme - Since 2004, the MOE provides this scheme to primary school students who are poor and weak in Mathematics, Science, Malay and English.

e. Textbook Loan Scheme (TLS) - TLS was launched in 1975 with the aim of providing textbook initially to poor and needy students. This programme was also aims to prevent students from dropping out of school or being left behind in their studies. And since 2008, TLS was given to every school going children in government and government aided school.

f. Hostels - Hostels are made available for primary and secondary students who stay far from school especially those from low-income families, in order to provide them with accommodation near their respective schools. At present, there are three types of hostels, which are regular school hostel, central hostel and fully residential school hostel. Regular school hostel provides accommodation only from a selective number of students in the school while central hostels accommodate students from several nearby schools while central hostels accommodate students from several nearby schools. Fully residential school hostel is a programme for excellent students especially those from rural areas and low-income families.

g. Federal Minor Scholarship (FMS) and University Preparatory Class Scholarship (UPCS) - The MOE awards these scholarships to secondary 
students who show outstanding academic, co-curricular and sport performance. Each year, about 200,000 students are awarded the FMS and 30,000 students the UPCCS

\section{THE EDUCATION DEVELOPMENT MASTER PLAN (2006-2010)}

4.1. The development of the national education is based on access, equity, quality, efficiency and effectiveness of management and the delivery system. Based on these basic thrusts, the MOE plans and implements education development policies to achieve the education goals that have been identified as follows:

- Developing the potentials of individuals in a holistic and integrated manner so as to produce individuals who are physically, emotionally, spiritually and intellectually balanced;

- Nurturing creativity, innovativeness and enhancing a learning culture among students;

- Acculturating science and technology as well as lifelong learning;

- Providing an efficient, effective and a world-class education system;

- Making Malaysia a centre of educational excellence; and

- Elevating the status of Malaysian education internationally

4.2. The MOE has formulated the Education Development Master Plan (EDMP) 2006-2010 as a comprehensive and integrated master plan for education development under $9^{\text {th }}$ Malaysia Plan (9MP). EDMP was developed in line with the national development plans and policies by taking into account the Third Outline Perspective Plan, Five Year Malaysia Plans, the framework laid out in the National Mission, the National Integrity Plan, Islam Hadhari and others including national education development plans and policies. The plan is aimed at «Pioneering Change: A National Mission» and put forward the policies the policies, goals, strategies, priorities, actions plans, key performance indicators, time-lines and budget for education development. The programmes and projects encompass three main components: the hardware, software and the people. 
4.3. The ultimate goal of EDMP is to provide quality education for all and two main approaches have been identified:

I. Complete tasks specified under the previous five-year Malaysia Plan to ensure access to education for all and to provide equal opportunities for all students; and

II. Further develop the potential of schools in their respective cluster of niche areas, enabling teachers and students to promote the schools and the national education system at the international level.

4.4. Under the first approach, the MOE is committed to ensure that all citizens receive fair and equal education opportunities regardless of location, race ability or ethnic background. The MOE will ensure all students master the reading, writing and arithmetic skills (3Rs) and that no student will drop out from the school system due poverty or location. Access to ICT especially the internet will be provided for all schools.

4.5. In cooperation with National Implementation Directorate and National Implementation Task Force, for the first time the MOE has prioritised quantum leap in rural education as crucial in narrowing the education gap. Programmes and projects have been identified encompassing preschool education, basic facilities, school infrastructure, school hostels, ICT initiatives, additional education programmes, teacher professional development and welfare and support programmes.

4.6. Under the second approach, special attention will be given to excellent schools to sustain and achieve greater successes. The MOE will identify schools in the respective clusters of national schools, nationaltype schools, fully residential schools, premier schools, technical schools, national religious secondary schools, centennial schools, smart schools and schools in Putrajaya and Cyberjaya. The MOE will identify niche areas that the schools within the clusters excel in and introduce various programmes to enhance the strengths and competitiveness of the schools. 


\section{Figure 1. Education Development Master Plan Framework, 2006 -2010.}

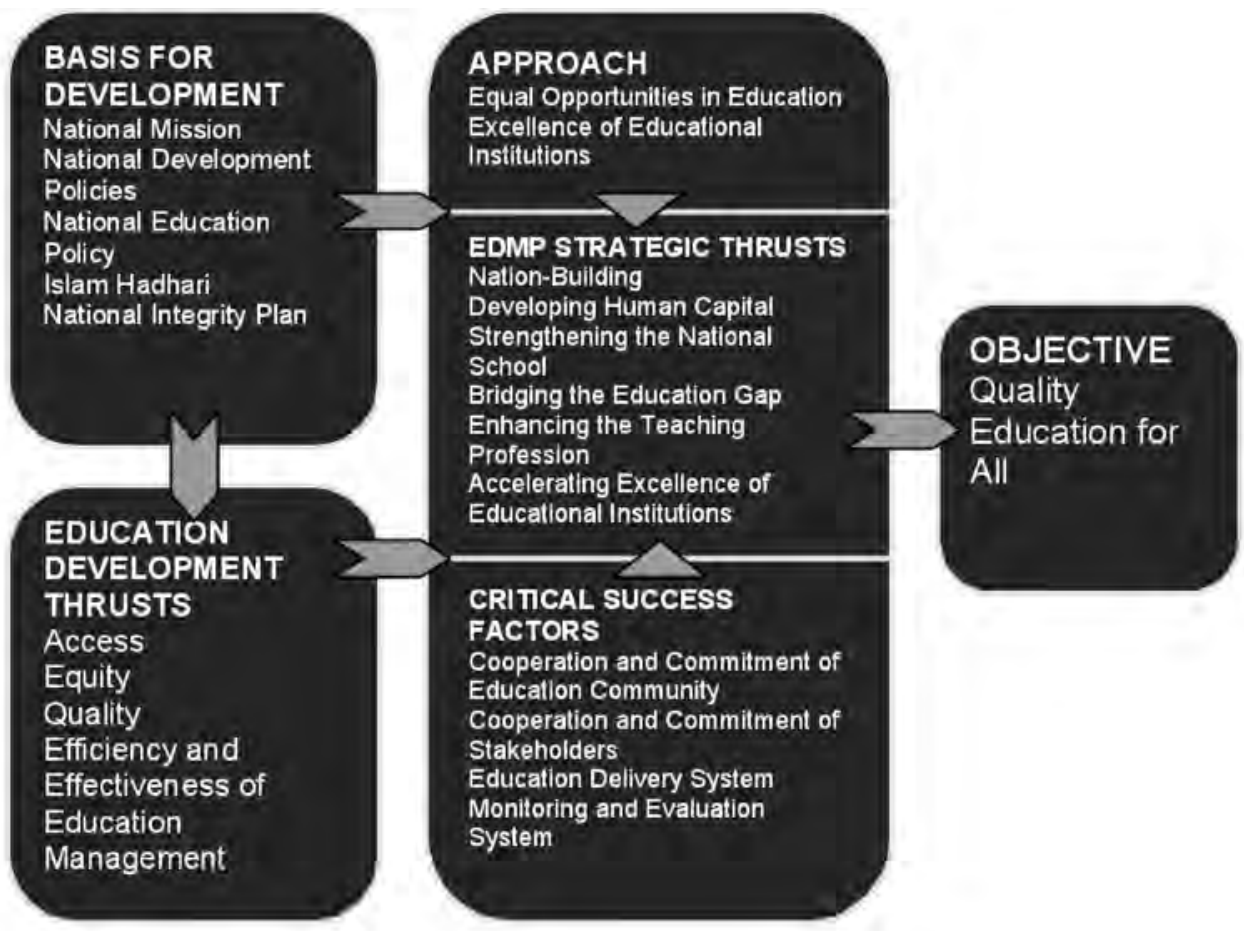

4.7. Figure 1 presents the conceptual framework of Educational Development Master Plan (2006-2010) which encompasses basis for development, education development thrusts, approaches, strategic thrusts, critical success factors and objective of EDMP. In designing the conceptual framework, various variables were considered in each component. Even though the framework implies a linear process, each component can feed back to improve inputs at the previous stage to ensure quality education for all. For example, specific action plans identified for the strategic thrusts may be modified during the implementation. Nevertheless, the foundations of the Plan, especially the policies and goals remain intact throughout. 


\section{STRATEGIC THRUSTS OF THE EDUCATIONAL DEVELOPMENT MASTER PLAN}

5.1. Six strategic thrusts have been formulated to strengthen the national education system:

Thrust 1: Nation-Building

Thrust 2: Developing Human Capital

Thrust 3: $\quad$ Strengthening National Schools

Thrust 4: $\quad$ Bridging the Education Gap

Thrust 5: Enhancing the Teaching Profession

Thrust 6: Accelerating Excellence of Educational Institutions

5.2. The first thrust focuses on nation-building through education. The MOE aspires to produce citizens from the formative school years with «global» and patriotic outlook, who value and treasure the cultural heritage and arts. The desire to build a nation can be achieved by strengthening the Malay language, improving students' discipline, fully implementing the Student Integration Plan for Unity (RIMUP) including co-curricular and sports activities to develop the identity and to cultivate positive traits and courtesy among students.

5.3. The second thrust focuses on the development of value systems, discipline and character building of students. This thrust aspires to produce students competent in Science and Technology, innovative, creative and marketable. The MOE will provide a holistic assessment and evaluation system, mould student discipline and emphasise on cleanliness, health and safety.

5.4. The third thrust focuses on strengthening the national schools (primary and secondary) as the «school of choice». In this regard, national schools will be well equipped with sufficient and quality education facilities including clean water, electricity and ICT infrastructure. These schools will have sufficient trained according to specialisation and support staff.

5.5. The MOE aims to bridge the education gap in terms of the provision of physical and non-physical amenities, students' achievements and 
dropout rate. Hence, in the fourth thrust, the MOE will continue to develop infrastructure and educational facilities especially in the rural areas of Sabah and Sarawak. These schools will be provided with the required infrastructure as stipulated under the 9MP. The MOE will also increase aid for poor students, students with special needs and minority groups, bridge the digital divide and emplace trained teachers according to subject specialisations in rural and interior areas.

5.6. The fifth thrust focuses on effort to enhance the teaching profession in line with the responsibility of moulding future generations. The MOE has upgraded teacher training colleges to Institute of Teacher Education to raise the qualification of teachers to degree level. The MOE will also improve the system for teachers to degree level. The MOE will also improve the system for teacher, services, placements and welfare.

5.7. The effort to accelerate excellence in educational institutions is through the establishment of cluster schools based on niche areas in particular academic, co-curriculum and sports. Selected schools in these clusters will be linked to renowned local and international institutions and become model schools. These schools will offer various examinations at the international level such as the International Baccalaureate. These schools will be benchmarked and showcased at the international level in line with effort to develop a quality and world-class education system.

\section{EDUCATION DEVELOPMENT MASTER PLAN 2006-2010: SUCCESS STORIES}

\section{High Impact Projects - A Quantum Leap to Rural Education}

6.1. The government has increased efforts to improve education in rural areas for the purpose of bridging the rural-urban gap, providing opportunities for students as well as ensuring their success. To reduce the education gap, the MOE, the National Implementation Directorate and the National Implementation Task Force (NITF) will implement 
identified high impact project within the 9MP encompassing infrastructure, provision of equipment, teachers, curriculum, aid programmes and support services such as:

- Expanding the MOE pre-school education programme by providing more than 2,400 pre-school classes in rural areas for about 61,000 children aged 5-6. including providing pre-school teacher training, computer and software facilities;

- Improving the provision of basic facilities such as 24-hour electricity supply for 900 schools and clean water supply for 300 schools;

- Providing sufficient and quality classroom facilities in rural areas including the extensions and replacement buildings as well as renovating and upgrading more than 2,600 primary and secondary schools;

- Providing new hostels and upgrading the existing hostels to accommodate about 65,000 students and to provide additional food allocation for 280,000 students;

- Increasing 5,000 remedial classes in rural areas to strengthen the mastery of the 3Rs;

- Expanding vocational subjects to 480 rural schools to provide more opportunities for less academically inclined students;

- Making rural schools smart by focussing on teaching and learning based on ICT by providing computer laboratories, access centres, teleconferencing, web-TV equipment, communication systems including satellite telephones and wireless facsimiles;

- Providing additional allocation for the Food Supplement Scheme (FSS) to cater for 550,000 rural students; and

- Providing incentives to location and level of hardship, travelling allowance to their hometowns, insurance for teachers, and renovation of teacher quarters including the supply of furniture.

\section{CRITICAL SUCCESS FACTORS}

7.1. Education is a national agenda that involves and requires the commitment of all stakeholders. Fullan (2007) emphasizes that «success is not just about being right; it is about engaging diverse individuals and groups who likely have different versions about what is right and wrong» (p. 40). Thus, one of the initiatives by the MOE is to address the capacity 
building in terms of its policy, strategy or action taken to ensure the stakeholders comprehend EDMP and be able to translate the theory into practice at their respective levels. As such, series of talks (ceramahs) on EDMP are carried out at all levels of education and non-governmental organizations (such as National Union Teaching Profession and Tamil Education Society) to provide in-depth information on EDMP and getting feedback to further improve EDMP. Thus, the success of the education system is based on its ability to benefit the target groups and raise the standard of living, and depends on the strong cooperation within and outside the MOE.

7.2. Educational issues are complex and sometimes beyond the control and expertise of the MOE to resolve it. All parties should be aware and accept the fact that the education agenda can be achieved together. The involvement, commitment and cooperation of various parties are important in ensuring that all information, communication, financial resources, manpower and expertise are efficiently and effectively managed to make the education agenda a success.

7.3. The success of the EDMP is dependent on the effective strategic planning at both macro and micro level. At the macro level, the MOE has established committees for each thrust to ensure the smooth implementation of the projects and programmes. These committees shoulder the responsibility to monitor, evaluate and provide a comprehensive to report every six months. Similar committees were set up at state, district and school levels to ensure all plans are executed at their respective levels.

7.4. The six strategic thrusts as outlined in the EDMP were further crystallized into implementation strategy which consists of action plan, activity, indicator, achievement indicator and target. Each activity is outlined with key performance indicators (KPI) which is represented in numbers or percentage.

\section{INTERNATIONALISATION}

8.1. In line with the efforts to enhance the quality of the national education, the MOE emphasize the need to continuously change in response 
to the demands at the global level. MOE needs to ensure that the education provided is on par with developed nations. In addition, MOE strives to provide and share knowledge, experience and best practices with other countries. For example, the Islamic education curriculum had received recognition by the International Bureau of Education in Geneva to be used in Afghanistan.

\section{CONCLUSION}

9.1. The development of education in Malaysia reflects the multi-faceted role it assumes in creating a united Malaysian society towards enhancing the quality of the lives of our children and generations to come. The new role of education has become fundamental and becoming more internationally focused through interdisciplinary, multicultural, cross-cultural studies and exchange of intellectuals. In this respect, the sharing of experience and ideas in this international intellectual discourse paves the way in establishing a functioning intellectual community across borders that reenergise the international collaboration and address the global issues such as interdependence, citizen and stewardship, quality of life, sustainable change, diversity, and persistence poverty. The challenges of globalisation and liberalisation have necessitated MOE to elevate the national education system to higher level to ensure the Malaysian are able to compete and contribute at the international level. 


\section{REFERENCES}

ABU ZAHARI, A.B., 1980, Perkembangan pendidikan di Malaysia sebelum merdeka hingga ke zaman sesudah merdeka, Kuala Lumpur, Penerbit fajar Bakti Sd. Bhd.

ALTBACH, P.G. \& KELLY, P.F., 1998, Textbooks in the Third World: policy, content and context, New York, Garland Publishing.

BAHAGIAN PERANCANGAN DAN PENYELIDIKAN DASAR PENDIDIKAN, 2007, Pelan Induk Pembangunan Pendidikan (20062010), Kuala Lumpur, Kementerian Pelajaran Malaysia.

FULLAN, M., 2007, The new meaning of educational change, New York, Teachers College Press.

HASSAN SAID, 2002, «Education and training for the K-based economy», in Jamaluddin Hj. Ahmad Damanhuri, Zulkurnain Hj. Awang \& Srojini Naidu (eds.), K-Based economy: Forging ahead for national transformation, Kuala Lumpur, National Institute of Public Administration (INTAN), p. 136-141.

MUKHERJEE, H., 1990, «Education and national development in Malaysia», in N.J. Entwistle (ed.), Handbook of educational ideas and practices, London, Routledge, p. 218-229.

NAIMAH ISHAK, 2000, Colonization and higher education: The impact of participation in western universities on Malaysian graduates who have returned to their academic and profesional lives (unpublished dissertation).

SENG, P.L.F., 1975, Seeds of separatism: Educational policy in Malaysia, Kuala Lumpur, Oxford University Press. 